\title{
Sustainability of Shallow Aquifer in Rumuohia Community, Emohua L.GA, Rivers State, Nigeria
}

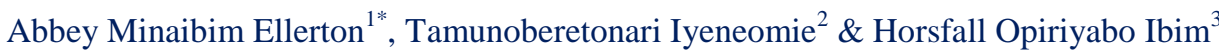 \\ ${ }^{1-3}$ Department of Physics, Rivers State University, Rivers State, Nigeria. \\ Email: abbeyminaibim@gmail.com ${ }^{1 *}$
}

DOI: http://doi.org/10.38177/ajast.2022.6107

Copyright: @ 2022 Abbey Minaibim Ellerton et al. This is an open access article distributed under the terms of the Creative Commons Attribution License, which permits unrestricted use, distribution, and reproduction in any medium, provided the original author and source are credited.

\section{ABSTRACT}

Around the world, groundwater is a key source of water. Because its reliance is growing, it is critical to ensure that a sufficient supply of high-quality drinking water is available. We explored the shallow aquifer in Rumuohia community in Emohua local government area, Rivers State, Nigeria, with the goal of using seismic refraction to delineate depth to the shallow aquifer and geological structure of the terrain at five selected areas. The result of the research reveals two strata with sand-gravel and clay lithologies. Layer 1 is clay, with an average velocity of $274.83 \mathrm{~m} / \mathrm{s}$ and a thickness range of $4.88 \mathrm{~m}$ to $9.98 \mathrm{~m}$ at an average of $7 \mathrm{~m}$ in all five locations. Layer 2 is composed up of sandy clay in Mina 1 and Mina 3. Clay is found in Mina 2, while sand with gravel (dry) is found in Mina 4 and Mina 5, implying a potential aquifer with an average velocity of $422.63 \mathrm{~m} / \mathrm{s}$. The presence of sand indicates a productive aquifer, while clay acts as a stopper for the sand, which is prone to compaction due to overburden pressure. The study area is generally a favorable location for a borehole with a high likelihood of providing drinkable water.

Keywords: Groundwater, Aquifer, Seismic refraction, Lithologies.

\section{Introduction}

Groundwater dependency is required to maintain a sufficient supply of high-quality drinkable water. In time past, some bore-holes were drilled in the Rumuohia community. Some dried up with time; some never yielded water. It is, therefore, necessary to delineate the aquifers in the area to drill sustaining bore-holes.

Several geophysical approaches are employed in delineating aquifers in an area. Amongst these are resistivity, up-hole and down-hole, seismic reflection, and refraction methods. In this study, we are adopting the seismic refraction approach to delineate aquifers in the community.

Seismic refraction is a geophysical technique for determining the thickness of fundamental geologic layers, water table depth, bedrock surfaces, engineering site characterisation, petroleum and mineral deposits. To characterize the route and velocity of the elastic disturbance in the ground, the subsurface is analyzed by generating arrival time and offset distance information. A hammer, explosives, weight drop (thumper truck), and seismic vibrator are used to create wave disruption in the subsurface. The first arrival time from the energy source is measured by detectors (geophones) spaced at regular intervals. The velocities and depths of the distinct strata can be estimated using the recorded signals (data) presented on time-distance graphs. This is plausible since the wave disturbance's rays (continuum points on the growing wavefront) follow a direct path and are the first energy to arrive at the close-in geophones. These rays are refracted at subsurface boundary layers where the elastic and density characteristics of the subsurface differ. The critically refracted beam follows the layer interface at the lower layer's velocity and continually "feeds" energy back to the surface, allowing the line of geophones to detect it (Haeni, 1986).

According to Todd (1959), a seismic wave's travel duration is determined by the medium it passes through; velocities are greatest in solid igneous rocks and lowest in unconsolidated materials (clay, silt, sand, and gravel). 
The more the formations and their borders can be determined, the more changes in seismic wave velocities are dictated by changes in elastic characteristics. The structure and geologic history of sedimentary rocks are more important than mineral composition. Wave velocity is reduced by porosity, but increased by water content. Seismic refraction methods have been used in a number of investigations across the world to determine groundwater potential and lithology. For example, Burwell, 1940; Sjogren and Wagner 1969; Galfi and Palos 1970; Followill, 1971; Shtivelman, 2002; Sundararajan et al. 2004; Venkateswara et al. 2004; Alhassan et al. 2010; Amir et al. 2012; Anomohanran, 2012; Bery, 2013; Thomas et al. 2013; Osumeje and Kudamnya, 2014; Adewoyin et al. 2016 and Abbey et al. 2022. Importantly, Galfi and Palos (1970) established that seismic refraction techniques may reliably detect the depth of water in sandy environments. They used a single-channel seismograph, a sledgehammer as the sound source, and 3.3-foot geophone spacing in their experiment. They calculated a depth to the water table of 13.3 feet, which matched the well log data of 13.1 feet. Furthermore, the up/downhole shooting technique has also been used to establish the weathering layer depth, thickness, and velocities in some parts of Niger Delta, Nigeria; as in Nwachukwu, 2001; Nwankwo et al. 2009; Adeoti et al. 2013; Anomohanran, 2014.

More specifically, Osagie (2009) investigated up-hole/down-hole thickness in the Southwestern Niger Delta and discovered that the thickness of the low velocity weathered layer in the area ranges from 3.6 to 46.2 meters, with an average of 24.0 meters. Ayolabi et al. (2009) conducted seismic refraction and resistivity studies in Igbogbo Township, South-West Nigeria, where they identified three layers: the first layer, which has a velocity of $150 \mathrm{~m} / \mathrm{s}$ to $336 \mathrm{~m} / \mathrm{s}$ and a thickness of $1.0 \mathrm{~m}$ to $3.3 \mathrm{~m}$; the second layer, made up of lateritic clay and has a thickness of $4.5 \mathrm{~m}$ to $10.5 \mathrm{~m}$ and has a velocity of 578 to $878 \mathrm{~m} / \mathrm{s}$. Igboekwe and Ohaegbuchu (2011) investigated the thickness and velocity of the weathering layer using the seismic refraction method, concluding that the findings are crucial in determining the time delays required for static adjustments during seismic reflection data processing.

In addition, Nwankwo et al. (2013) investigated groundwater potential in portions of Rivers State, Nigeria, using the seismic refraction method. Their findings revealed a three-layer subsurface model, with the aquifer layer having an average velocity of 500 meters per second and depths ranging from 12.52 meters to 26.56 meters. The refraction results were highly associated with the area's resistivity measurements, which revealed an aquifer depth range of $14.48 \mathrm{~m}$ to $53.68 \mathrm{~m}$. Nwosu and Emujakporue (2016) investigated the thickness and velocity of the weathered layer in Emohua town using the seismic refraction method and discovered two layers: the weathered layer and the sub-weathered layer. The velocity and thickness of the weathered layer range from $255.55 \mathrm{~m} / \mathrm{s}$ to $312 \mathrm{~m} / \mathrm{s}$ and $1.60 \mathrm{~m}$ to $1.89 \mathrm{~m}$, respectively. At an unknown thickness, the sub-weathered layer has a velocity varying from $346.94 \mathrm{~m} / \mathrm{s}$ to $368 \mathrm{~m} / \mathrm{s}$. They concluded that their findings can be used in both groundwater exploration and site characterization in civil engineering. This study is aimed at utilizing the seismic refraction method to delineate depth to shallow aquifer and geological structure of the terrain in Rumuohia Community in Emohua local government area.

\section{Location and Geology of the Study Area}

Emohua Town is the headquarters of the Emohua Local Government Area in Rivers State, Nigeria. It consists of eight sub-communities, namely: Elibrada, Isiodu, Mbu-eto, Mbuitanwo, Oduoha, Rumuakunde, Rumuohia, and Rumuche. They are usually written with the suffix -Emohua attached to them such as Rumuohia-Emohua. 


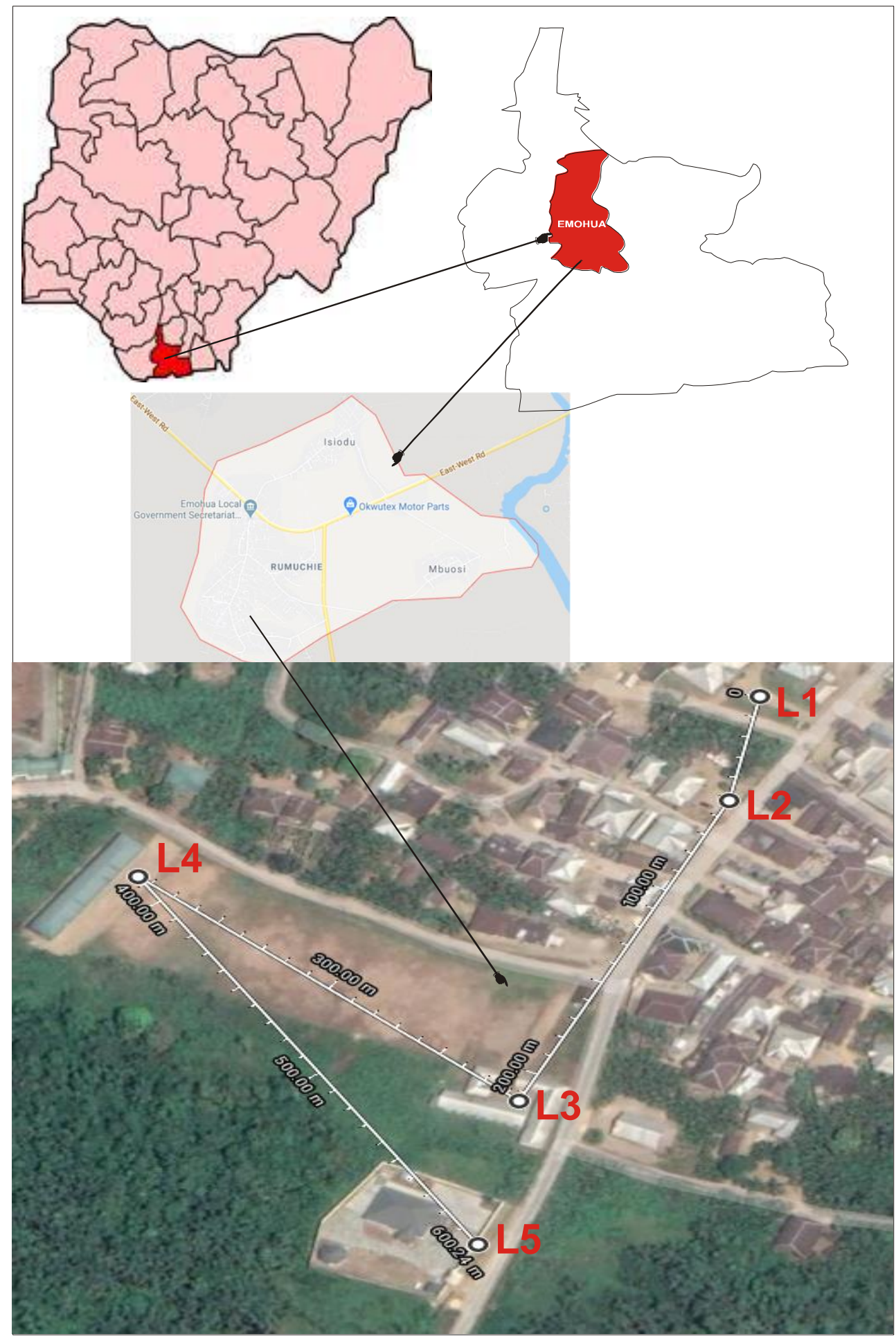

Fig.1. Map of the Study Area

Our selected area of study is Rumuohia-Emohua. It is located in the Niger Delta Sedimentary basin of Nigeria, with an area of $831 \mathrm{~km}^{2}$ (321 sq mi) and a population of 201,901 according to the 2006 census. It is located at Latitude 453'2" North and Longitude 651'39" East (Fig.1). On the West African continental margin, the Niger Delta sedimentary basin covers an area of around 200,000 square kilometers. The Akata, Agbada, and Benin Formations are the three stratigraphic units that make up this formation. The Akata Formation is a marine shale unit that is under-compacted in most areas and may contain lenses of exceptionally high-pressured siltstone or fine-grained sandstone. It is the face of the pro-Delta faction. 
Agbada Formation is the for formation which directly lies on top of the Akata Formation and it consists of a sequence of sand and sandstone bodies intercalated with shale. Local transgressions and regressions give rise to the intercalation of sands, sandstone, and shale. Agbada Formation ranges in age from Eocene to Holocene with about 3000 meters thick (Reyment, 1965; Okwueze, 2011).

The Benin Formation is the topmost unit of the Niger Delta. The formation is predominantly sandy containing over ninety percent grains of sand and sandstones, with a few shale intercalations which become more abundant towards the base. The formation generally exceeds 2000 meters in thickness and ranges in age from Miocene to Recent. The total thickness of sediments in the Niger Delta may be as much as 12,000 meters (Osumeje and Kudamnya, 2014).

\section{Methodology}

\subsection{Materials}

The following materials were used: energy sources, geophones (sensor or detector), seismograph (recording device), a global positioning system (GPS), measuring tape, peg sticks, and 12 volts DC battery.

\subsection{Data Acquisition}

A 12-channel seismograph (ABEM Terraloc Mark 6) was used with an energy source of a 16kg sledgehammer striking a steel plate. A total of five (5) in-line profiles at continuous profiling of 120 metres were used. The technique consisted of laying out twelve (12) geophones at an interval distance of 10metres which is marked with tape and pegged in a straight line and recording arrival times from shot points produced by striking a $16 \mathrm{~kg}$ sledgehammer onto a steel plate at the end of the geophone spread. The signals received by the geophones as obtained on the recording unit were displayed on the screen as traces and three strikes were made for sharp peaks and better troughs. The GPS and the compass were used to know the elevations and the bearing of the location under observation to the North Pole. The seismograph has an option for picking of arrival time automatically and the recording unit had digital incoming signals, thus random background noise caused by the ground vibrations can be minimized in the final record.

\subsection{Data Processing}

ReflexW version 3.0 was used to handle and interpret the seismic refraction data (Sandmeier, 2002). The data collected from the field was subjected to different stages of processing to enhance the signal-to-noise ratio. The signal quality was improved by applying a bandpass filter (ranging from $150 \mathrm{~Hz}$ and $50 \mathrm{~Hz}$ ).

Manually pick the first arrival times and the ray-tracing method is used to calculate the ray paths (see Parasnis et al. 1997). The layers' velocities can be computed by taking the reciprocal of the slopes obtained by plotting the travel time against offset distance and equation 1 below can be used to estimates it depth.

$\mathrm{Z}=\frac{X_{c r}}{2} \sqrt{\frac{\mathrm{V}_{2}-\mathrm{V}_{1}}{\mathrm{~V}_{2}+\mathrm{V}_{1}}}$

Where, $V_{1}$ is the velocity of the first layer; $V_{2}$ is the velocity of the second layer, $X_{c r}$ is the crossover distance and $t_{i}$ is the intercept time. 


\section{AJAST}

Asian Journal of Applied Science and Technology (AJAST)

Volume 6, Issue 1, Pages 50-60, January-March 2022

\section{Geological Interpretation/Results}

Since it is a shallow subsurface survey, and the study areas are overlain by cretaceous and tertiary sediment. From standard data for P-wave propagation as shown in Table 1, we make inferences on the lithology.

Table 1. Established Standard P-Wave Velocity (Ugwu, 2010)

\begin{tabular}{|c|c|}
\hline Rock Type & Standard P-Wave Velocities (m/s) \\
\hline Granite & $5520-5640$ \\
\hline Sandstone & $1400-4300$ \\
\hline Limestone & $1700-4200$ \\
\hline Clay & $110-2500$ \\
\hline Loose Sand & 1800 \\
\hline Coarse Sand (wet) & $1150-1670$ \\
\hline Sand with gravel (wet) & $690-1150$ \\
\hline Sand with gravel (dry) & $430-690$ \\
\hline Sand clay & $360-430$ \\
\hline
\end{tabular}

The summary of results of the seismic refraction surveys carried out at five (5) locations in the Rumuohia community is presented in both tables and figures.

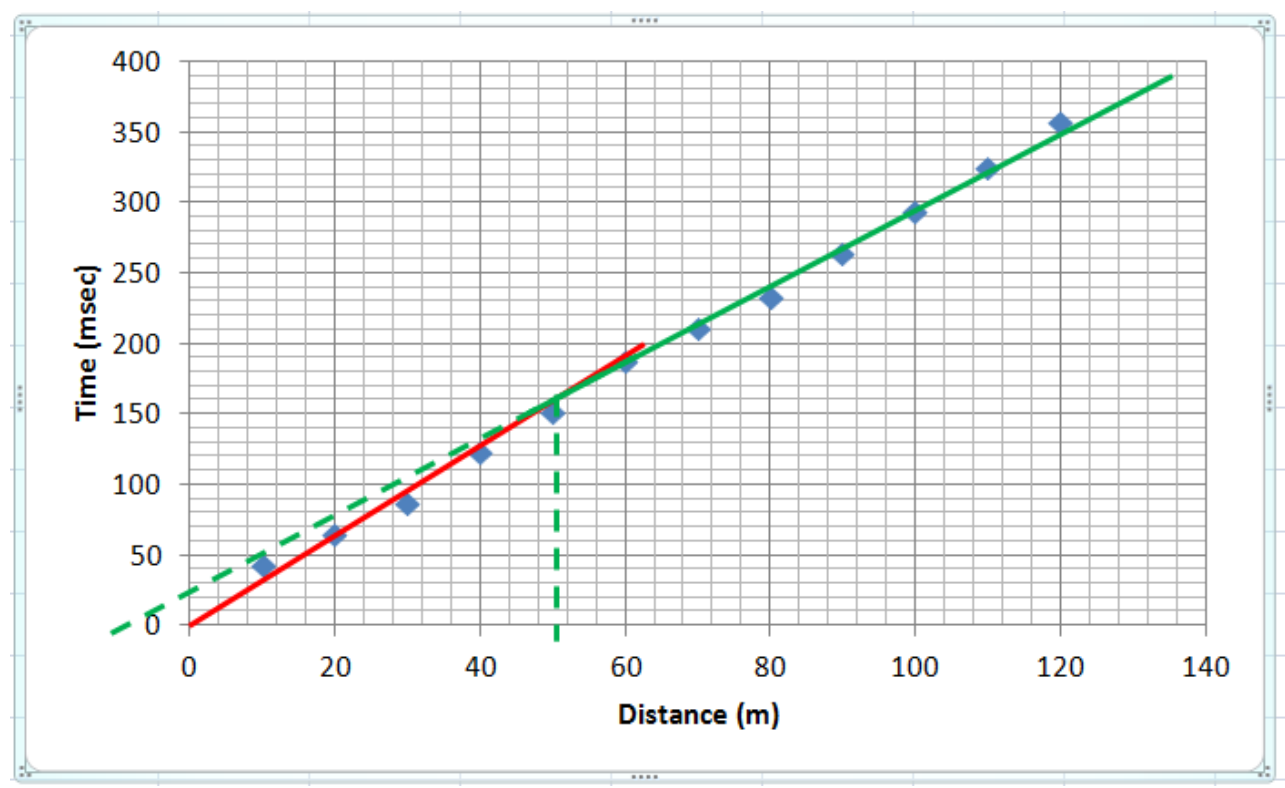

Fig.2. Travel time Vs Offset distance of Mina 1 
Asian Journal of Applied Science and Technology (AJAST) Volume 6, Issue 1, Pages 50-60, January-March 2022

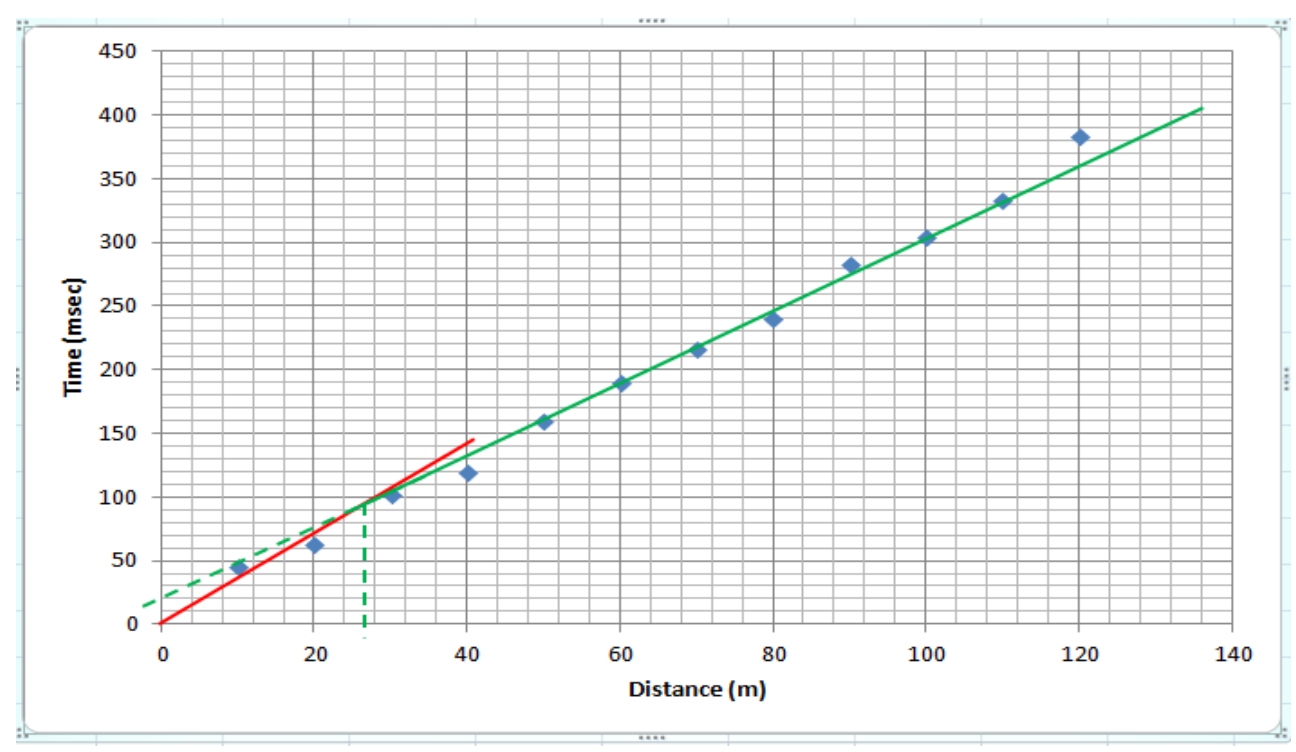

Fig.3. Travel time Vs Offset distance of Mina 2

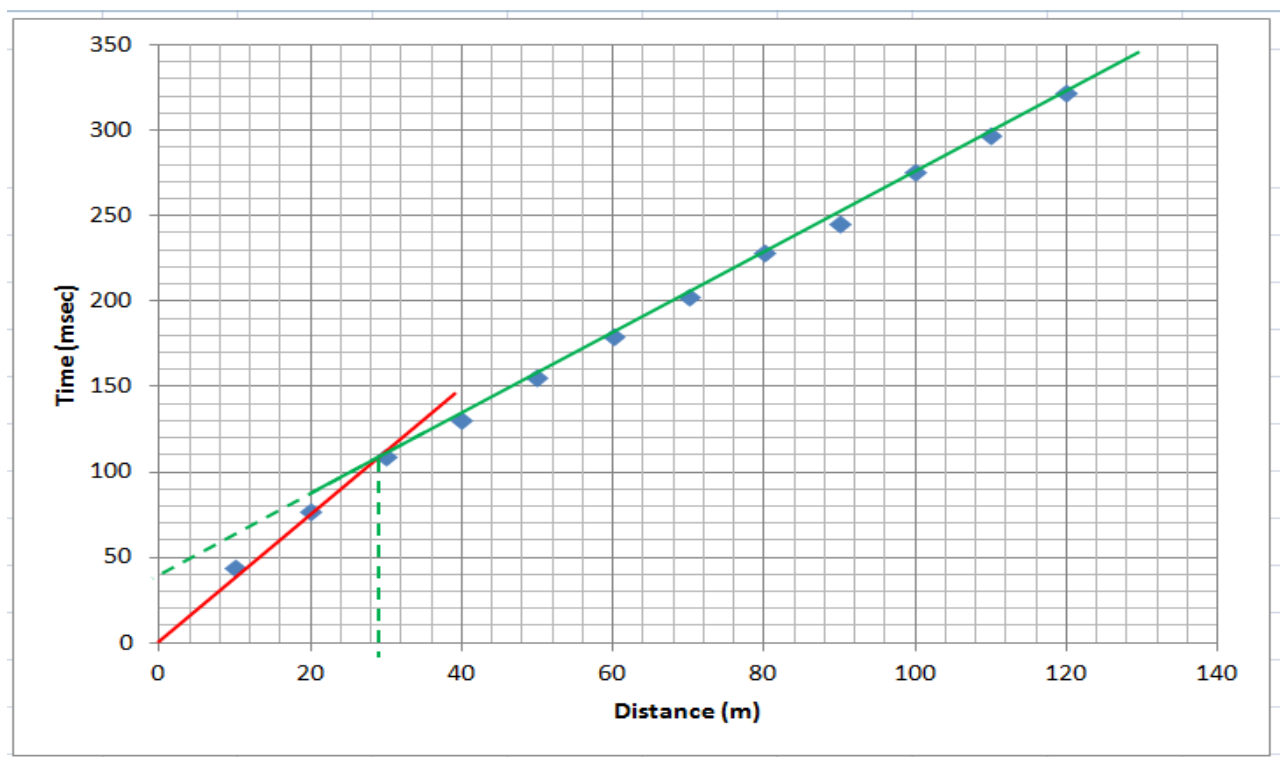

Fig.4. Travel time Vs Offset distance of Mina 3

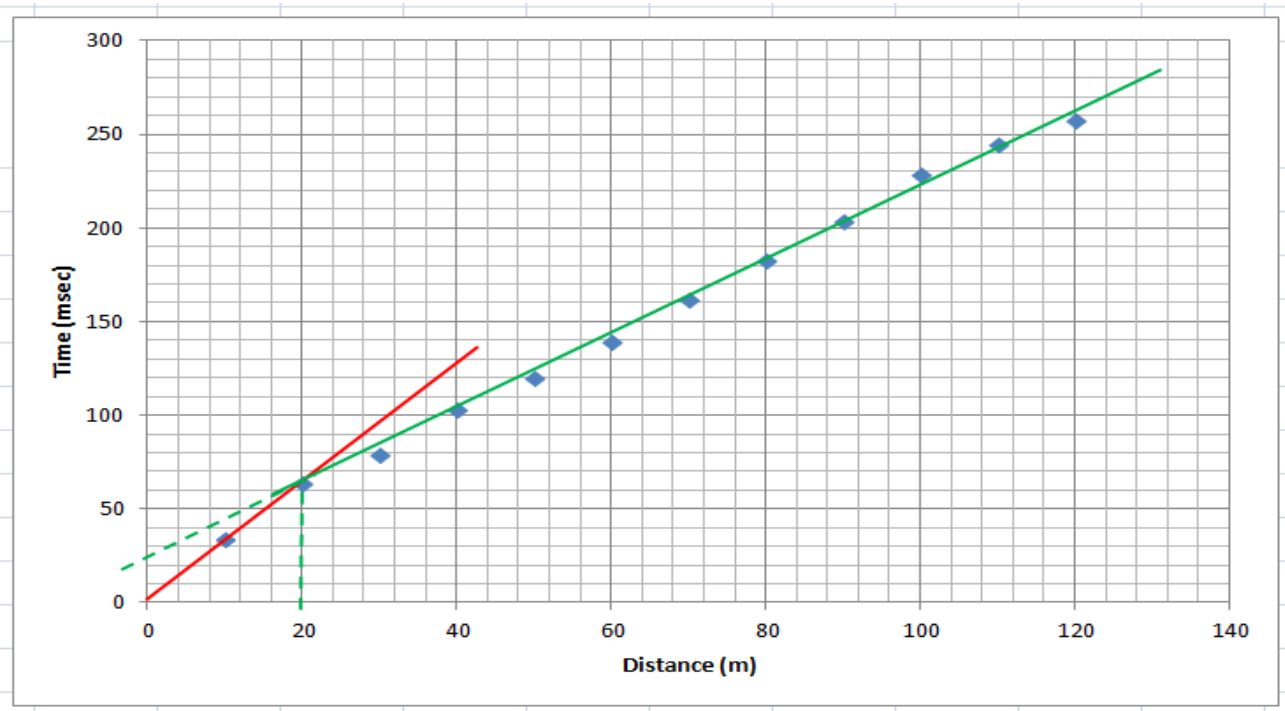

Fig.5. Travel time Vs Offset distance of Mina 4 


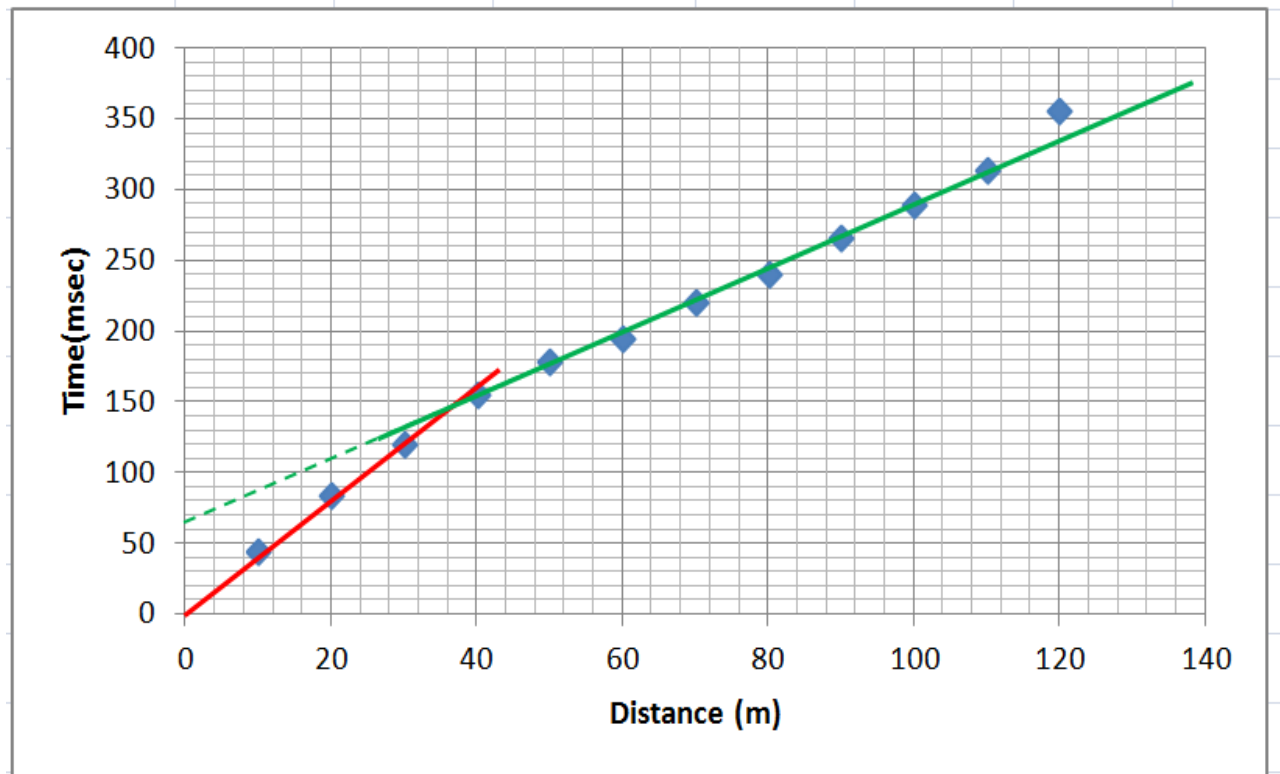

Fig.6. Travel time Vs Offset distance of Mina 5

Table 2. Results Summary

\begin{tabular}{|c|c|c|c|c|c|}
\hline Location & \multicolumn{2}{|c|}{ Velocity (m/s) } & Depth (m) & Geologic Implication & Xer (m) \\
\hline \multirow[t]{2}{*}{ Mina 1} & $\mathrm{~V}_{1}$ & 315.79 & 7.32 & Clay & \multirow{2}{*}{50} \\
\hline & $\mathrm{V}_{2}$ & 375.00 & & Sandy Clay & \\
\hline \multirow[t]{2}{*}{ Mina 2} & $\mathrm{~V}_{1}$ & 240.00 & 5.83 & Clay & \multirow{2}{*}{27} \\
\hline & $\mathrm{V}_{2}$ & 350.00 & & Clay & \\
\hline \multirow[t]{2}{*}{ Mina 3} & $\mathrm{~V}_{1}$ & 266.67 & 6.99 & Clay & \multirow{2}{*}{29} \\
\hline & $\mathrm{V}_{2}$ & 428.13 & & Sandy Clay & \\
\hline \multirow[t]{2}{*}{ Mina 4} & $\mathrm{~V}_{1}$ & 311.69 & 4.88 & Clay & \multirow{2}{*}{20} \\
\hline & $\mathrm{V}_{2}$ & 506.67 & & Sand with Gravel (dry) & \\
\hline \multirow[t]{3}{*}{ Mina 5} & $\mathrm{~V}_{1}$ & 240.00 & 9.98 & Clay & \multirow{2}{*}{36} \\
\hline & $\mathrm{V}_{2}$ & 453.33 & & Sand with Gravel (dry) & \\
\hline & Average & & 7.00 & & 15 \\
\hline
\end{tabular}

\section{Discussions}

The graphs (Fig. 2, 3, 4, 5, and 6) showed that the model is of two layers namely: layer 1 and layer 2. At Mina 1, layer 1 has a velocity $\left(\mathrm{V}_{1}\right)$ of $315.79 \mathrm{~m} / \mathrm{s}$ at a depth of $7.32 \mathrm{~m}$ and layer 2 a velocity $\left(\mathrm{V}_{2}\right)$ of $375 \mathrm{~m} / \mathrm{s}$ at an unknown depth. In comparism with the standard P-wave velocities, it shows that layer 1 is made up of clay lithology while layer 2 is of sandy clay lithology; see Table 1 and 2.

At Mina 2, layer 1 has a velocity $\left(\mathrm{V}_{1}\right)$ of $240 \mathrm{~m} / \mathrm{s}$ at a depth of $5.83 \mathrm{~m}$ and layer 2 a velocity $\left(\mathrm{V}_{2}\right)$ of $350 \mathrm{~m} / \mathrm{s}$ at an unknown depth. In comparism with the standard P-wave velocities, it shows that both layers are made up of clay. At Mina 3, layer 1 has a velocity $\left(\mathrm{V}_{1}\right)$ of $266.67 \mathrm{~m} / \mathrm{s}$ at a depth of $6.99 \mathrm{~m}$ and layer 2 a velocity $\left(\mathrm{V}_{2}\right)$ of $428.13 \mathrm{~m} / \mathrm{s}$ at an 


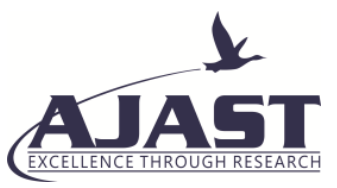

Asian Journal of Applied Science and Technology (AJAST)

Volume 6, Issue 1, Pages 50-60, January-March 2022

unknown depth. In comparism with the standard P-wave velocities, it shows that layer 1 is of clay while layer 2 is of sandy clay.

At Mina 4, layer 1 has a velocity $\left(\mathrm{V}_{1}\right)$ of $311.69 \mathrm{~m} / \mathrm{s}$ at a depth of $4.88 \mathrm{~m}$ and layer 2 a velocity $\left(\mathrm{V}_{2}\right)$ of $506.67 \mathrm{~m} / \mathrm{s}$ at an unknown depth. In comparism with the standard P-wave velocities, it shows that layer 1 is of clay while layer 2 is of sand with gravel (dry).

At Mina 5, layer 1 has a velocity $\left(\mathrm{V}_{1}\right)$ of $240 \mathrm{~m} / \mathrm{s}$ at a depth of $9.98 \mathrm{~m}$ and layer 2 a velocity $\left(\mathrm{V}_{2}\right)$ of $453.33 \mathrm{~m} / \mathrm{s}$ at an unknown depth. In comparism with the standard P-wave velocities, it shows that layer 1 is of clay while layer 2 is of sand with gravel (dry). In summary, layer 1 in all five locations is made up of clay with an average velocity of 274.83m/s. Layer 2 in Mina 1 and Mina 3 are made up of sandy clay. In Mina 2, it is clay while in Mina 4 and Mina 5 , it is sand with gravel (dry), which infers a potential aquifer with an average velocity of $422.63 \mathrm{~m} / \mathrm{s}$. The thicknesses of layer 1 in all locations are in the range of $4.88 \mathrm{~m}$ to $9.98 \mathrm{~m}$ with an average thickness of $7 \mathrm{~m}$ while that of layer 2 is infinite or unknown due to the energy source (sledge hammer) which cannot generate a stronger seismic signal when compared to explosives. Some bore-holes drilled in the Rumuohia community yielded water for a very short period and stopped because people neglect to delineate the aquifer before drilling. Also, this can be attributed to the fact that some people drill during the wet season when the water table is closed to the surface and during the dry season the well becomes dried up.

\section{Conclusions}

We delineate shallow aquifers in the Rumuohia community at five selected locations using the seismic refraction method with the aim of sustaining groundwater supply in the community irrespective of the season. The followings were revealed:

- The analysis of the result shows two layers with the presence of sand-gravel and clay lithologies.

- A minimum of $7 \mathrm{~m}$ should be drilled irrespective of the topography/season in the Rumuohia community to access a saturated zone.

- Rumuohia is generally a good site for borehole with a high tendency for good water supply for home use.

- The seismic Refraction Method can be used for aquifer delineation in Emohua local government area which has not been used before.

\section{Declarations}

\section{Source of Funding}

This research did not receive any grant from funding agencies in the public, commercial, or not-for-profit sectors.

\section{Competing Interests Statement}

The authors declare no competing financial, professional and personal interests.

\section{Consent for publication}

Authors declare that they consented for the publication of this research work. 


\section{Authors' contributions}

All authors whose names appear in this article made substantial contributions in the following ways: conception or design of the work, analysis, and data interpretation.

\section{References}

Abbey ME, Tamunobereton-Ari I, Horsfall OI (2022) Aquifer Delineation Using Seismic Refraction Method in Rumuohia Community, Emohua L.G.A., Rivers State, Nigeria. Earth Sciences Pakistan, 6(1): 17-21.

Adeoti L, Ishola KS, Adesanya O, Olodu U, Bello MA (2013) Application of Uphole Seismic Refraction Survey for Sub-surface investigation: Case Study of Liso-Field Niger Delta Nigeria. World App. Sci. J., 26(5): 573-582.

Adewoyin OO, Joshua EO, Akinyemi1 ML (2016) Application of Shallow Seismic Refraction Method and Geotechnical Parameters in Site Characterization of a Reclaimed Land, Indian Journal of Science and Technology, 9(45): 1-7, DOI: 10.17485/ijst/2016/v9i45/82091.

Alhassan DU, Dangana LM, Salako KA, Jonah SA, Ofor NP (2010) Seismic Refraction Investigation of the Subsurface Structure at the Southern Part of Niger State College of Education, Minna, Nigeria, Bayero Journal of Pure and Applied Science, 3(2): 56-61.

Amir G, Ahmed M, Haydar B, Khalid B, Hasan A, Saber M, (2012) The use of seismic refraction and electrical techniques to investigate groundwater aquifer, wadi al-ain, United Arab Emirates (UAE), Conference Proceedings, Tulcea - Romania, ISBN: 978-606-605-038-8

Anomohanran O (2012) Geophysical interpretation of seismic reflection data obtained from Umureute and Amiynaibo area of Delta State, Nigeria. Nigerian Journal Sci. Environ., 11: 148-153.

Anomohanran O (2014) Downhole Seismic Refraction Survey of weathered layer characteristics in Escravos, Nigeria. American Journal of Applied Sciences, 11(3): 371-380.

ASTM International (ASTM), 2000, d5777 Standard guide for using the seismic refraction method for subsurface investigation. An annual book of ASTM standards, volume 04, 08. Soil and rock (1) and volume 04. 08, soil and rock (2)., West Conshocken Pennsylvania, ASTM.

Ayolabi EA, Adeoti L, Oshiniaja NA, Adeosun IO, Idowu OI (2009) Seismic Refraction and Resistivity Studies of Igbogbo Township, South -West Nigeria. Journal of Sci. Res. Dev. 11: 42-61.

Bery A (2013) High Resolution in Seismic Refraction Tomography for Environmental Study," International Journal of Geosciences, 4(4): 792-796. DOI: 10.4236/ijg.2013.44073.

Burwell EB (1940) Appendix A-Determination of ground-water levels by the seismic method, Eos Trans. AGU, 21(2): 439- 440, DOI: 10.1029/TR021i002p00439.

Emerson DW (1968) The determination of ground-water levels in sands by the seismic-refraction method: Civil Engineering Transactions, 10(1): 15-18. 
Asian Journal of Applied Science and Technology (AJAST)

Volume 6, Issue 1, Pages 50-60, January-March 2022

Followill FE (1971) Shallow seismic-refraction mapping of Eocene water tables, northern Mississippi, Completion report: Mississippi State, Miss., Mississippi State University Water Resources Research Institute, 14.

Galfi J, Palos M, (1970) Use of seismic refraction measurements for groundwater prospecting. International Association of Scientific Hydrology. Bulleting, 15(3): 41-46. DOI: 10.1080/02626667009493971

Shtivelman V (2002) Surface wave sections as a tool for imaging subsurface inhomogeneities. European Journal of Environmental and Engineering Geophysics. 7. 121-138.

Haeni FP (1986) Application of Seismic Refraction methods in groundwater modelling studies in New England. http://library.seg.org. Geophysics, 51(2): 236-249.

Igboekwe MU, Ohaegbuchu HE (2011) Investigation into the Weathering Layer Using Uphole Method of Seismic Refraction Journal of Geology and Mining Research 3(3): 73-86

Nwachukwu MA (2001) Determination of Weathering depth by uphole Shooting Technique in some parts of Owerri, South- eastern Nigeria. Global Journal of Pure and Applied Sciences. 9(4): 533-538.

Nwankwo CN, Ebeniro JO, Ekine AS (2009) The use of Uphole Method in the Mapping of the Thickness and Velocity of the Low-Velocity Layer in Parts of the Eastern Niger Delta, Nigeria. Nig. Journ. Phys. 21(1): 64-71.

Nwankwo CN, Emujakporue GO, Nwosu LI (2013) Seismic refraction investigation for groundwater potential in parts of Rivers State, Nigeria. Pacific Journal of Science and Technology, 14(2): 505-511.

Nwosu LI, Emujakporue GO (2016) Seismic refraction investigation of thickness and velocity of the weathered layer in Emohua town, Rivers State, Nigeria. Journal of Applied Geology and Geophysics, 4(6): 52-57.

Osagie EO (2009) Weathering Structure of Southwestern Niger Delta, Nigeria. Pacific Journal of Science and Technology. 10(2): 672-679.

Osumeje JO, Kudamnya EA (2014) Hydro-geophysical Investigation Using Seismic Refraction Tomography to Study the Groundwater Potential of Ahmadu Bello University Main Campus, within the Basement Complex of Northern Nigeria. Journal of Environment and Earth Science, 4(2): 15-22.

Sjogren B, Wager O (1969) On a soil and ground-water investigation with the shallow refraction method at Mo I Rana: Engineering Geology, 3(1): 61-70.

Sundararajan YS, Narasimha MC, Nandakumar G, Hanmantha A (2004) Delineation of structures favourable to groundwater occurrence employing seismic refraction method: A case study from Tiruvuru, Krishna district, Andhra Pradesh Proc. Indian Acad. Sci. (Earth Planet. Sci.), 113( 3): 259-267.

Thomas S, Benjamin W, Anne AS (2013) Case study of a geophysical investigation with seismic refraction tomography and the Ohm Mapper to estimate the brine content of a Salar/Salmuera. Near Surf. Geo., 31:85-90.

Todd DK (1959) Ground Water Hydrology. John Wiley \& Sons, Inc., New York, London. 14-34, 219-229.

Ugwu SA (2010) Determination of the Depth to Bedrock in Afikpo Syncline of the Benue Trough, Nigeria. World Journal of Applied Science and Technology, 2(1): 19-25. 


\section{AJAST}

Asian Journal of Applied Science and Technology (AJAST)

Volume 6, Issue 1, Pages 50-60, January-March 2022

Ugwu SA, Nwankwo CN (2013) Determination of Elastic Constants and Seismic Velocity of Unconsolidated Layers around the Greater Port Harcourt City, Rivers State, Nigeria. Pacific Journal of Science and Technology, 14(2): 551-564.

Venkateswara R., Raju JS, Rao BSP, Rao PK (2004) Bedrock investigation by seismic refraction method-A case study. J. Ind. Geophys. Union, 8(3): 223-228.

Weli VE, Ogbonna VA (2015) An Analysis of Well Water Quality and the Incidence of Water Borne Diseases in Emohua Communities, Rivers State, Nigeria. International Journal of Environment and Pollution Research, 3(2): $32-41$. 